\title{
Human Capital Improvement on Informal Businesses
}

\author{
${ }^{1}$ Tinneke Evie Meggy Sumual* \\ Management study program \\ Faculty of Economics \\ Universitas Negeri Manado \\ Tondano, Indonesia \\ tinnekesumual@unima.ac.id
}

\author{
${ }^{2}$ Grace J. Soputan \\ Social Studies Education Study \\ Program \\ Faculty of Economics \\ Universitas Negeri Manado \\ Tondano, Indonesia \\ gracesoputan@unima.ac.id
}

\author{
${ }^{3}$ Arie F. Kawulur \\ Management study program \\ Faculty of Economics \\ Universitas Negeri Manado \\ Tondano, Indonesia \\ ariekawulur@unima.ac.id
}

\begin{abstract}
The purpose of this paper is to analyze the effect of the human capital improvement on business development implemented by women in informal businesses, called Tibo-Tibo fish business in North Minahasa Regency. This research method utilises one group pretest-posttest experiment design and data were collected utilising a questionnaire technique for 55 women who were selected purposively to develop business. Another data collection procedure is a market survey that targets to discover what sorts of products which have marketing opportunities based on consumer needs. Data were analyzed by means of two difference analysis techniques with T-Test followed by Regression test. The results exhibited a significant difference before and after the training. Other findings exposed that there was an increase in knowledge and skills in product diversification, innovation and marketing strategies, and an increase in entrepreneurial attitudes which affect the development of a business.
\end{abstract}

Keywords: Human Capital, Improvement, Informal Businesses

\section{INTRODUCTION}

Business in the informal sector is an economic activity which does not only have an economic but also social impact on community, as implied from the paper "The Role of Informal Micro-Entrepreneurs in the Development of a Rural Border Region [1]. The article suggested that the informal sector has a very wideranging role such as creating employment, supporting to diversify economic activities, providing raw materials for local producers, helping to reduce poverty and even a broader role which is driving countries' development. Other research believes that the informal sector nurtures in the city's suburbs, hence this sector impacts the movement of labour from rural to urban areas [2]. Ease of doing business becomes the determining factor for this business which is increasingly dominant in Indonesia such as not requiring large capital, inadequate skills, business flexibility and not bound by business regulations. The proportion of the growth in the informal sector is also a result of globalization, capital mobility, restructuring of the production of goods and services (due to the limited capacity of formal industries to absorb the existing workforce, so there is a tendency that the informal sector appears in the suburbs of big cities [3]. Informal sector does not only increase family income in rural and urban areas, but also the absorption of labour, poverty alleviation and economic improvement in the development of information technology and the impact of globalization.

The economic activity in the informal sector is growing in Indonesia in various business fields such as 1) Processing industries (fish processing industry, food and beverage; 2) Transportation such as private car taxi, taxi bike, Becak, Andong, Bentor, etc. 3) Trade (stalls, food traders, beverage traders, clothing traders, second-hand merchants, household goods traders, etc.); 4) Services include selling credit, sewing, laundry, catering, masseur, etc.). The informal sector does not mean illegal economic activity. The ILO for the first time launched a program for the World Employment Program (WEP) and has introduced the concept of the informal sector in the world since 1972.

Meanwhile, the informal sector is considered a concept whose economic activities are outside the aspects of regulation and taxation since 1990. The informal sector has the following features: a) ease of entry; b) reliance on indigenous resources; c) family ownership of enterprises; d) small scale of operation; e) labourintensive and adapted technology; f) skilled acquired outside the formal school system; and g) unregulated and competitive markets [4]. There are 11 informal sector indicators proposed by Sukesi et al (2002) in his research on Social Security for Basar and Kali Lima Traders, namely: 1) Organization (unorganized business activities), 2) Business licenses (no business licenses), 3) Activity patterns (irregular activity patterns), 4) Policies (policies and assistance from the government are absent), 5) Business units (workers can easily go in / out), 6) Technology (use of technology is still simple), 7) Capital and business scale are relatively small, 8) Education (does not require formal education), 9) management (done alone, laborers come from families), 10) Products (consumed by the lower middle class), 11) Capital in this case is self-owned capital or takes informal credit [3].

With regard to business ownership, a survey in 2011 disclosed that businesses owned by women in urban areas were around $52.9 \%$ microenterprises, small businesses 
$50.6 \%$ and medium enterprises $34.0 \%$. Assuming that this proportion did not change during the 2013-2015 period, then women's small businesses contributed IDR 443 trillion (USD 36.5 billion) and women's mediumsized businesses amounted to IDR 421 trillion (USD 34.6 billion) in Indonesia's GDP in 2013, or overall around 9.1\% of the GDP (International Finance Corporation, 2016). Women's roles in a variety of economic activities are increasingly wide open along with the development of gradually globalized civilization and the influence of information technology that unlocks women's principles in business. A male-controlled culture which has been weakening women to act as entrepreneurs is progressively eroded, thus women contribute to the improvement of economic development even more.

The business of "Tibo-tibo" fishing women is one of the economic activities in the informal sector that is conducted by women by selling fish while carrying baskets around the village and selling fish in the local market. This economic activity has long been held by women who live on the coast with the intention of obtaining benefits in order to increase the income of their family. The Tibo-tibo business which is held by fisher women in North Minahasa Regency is limited to buying and selling fresh fish with very diverse profits ranging from IDR 500,000/month to IDR 2,000,000/month. High and low profits obtained through this effort is very dependent on weather factors. The economic activity of this business is limited to only selling fresh fish in limited quantities. They have not had a network and marketing strategy yet, consequently if fish stocks are large and not sold out, fish will be sold inexpensively otherwise fish will be rotten. If they stay in this condition, they will remain poor, hence new business behaviour requires to be developed to be more innovative.

Tibo-tibo fisherwomen's business has a great prospect to develop into an innovative and sustainable business because in addition to being supported by the availability of potential fish, community demand for processed fish products is also increasingly high and the location of the Tibo-tibo fisherwomen's business is even located in the Special Economic Zone of Tourism, a strategic area for business development. From numerous opportunities to develop business, various human capital problems inherent in Tibo-tibo fisherwomen are identified as lack of knowledge and skills in product diversification and marketing innovation, lack of creativity, lack of competence and entrepreneurial attitudes.

Human capital improvement in the informal sector is very vital to generate human resources so that they will have the capability, creativity and innovation that will have an impact on business development. Human capital is a valuable asset for business organizations, subsequently business organizations with low human capital are projected to disrupt the organization to work effectively and efficiently. Human capital is different from other capital such as technological capital, financial capital, natural capital and social capital. Human capital is recognized as a source of organizational value creation [5], as one dimension of intellectual capital [6]-[8] which is inherent in a person in the form of knowledge, skills, competency, and innovation [9]. Another dimension of human capital is seen in an article on "The Value of Human and Social Capital Investments for Business Performance of Startups" looking at 3 main dimensions namely experience, age and education level [10]. Human capital is related to traits one brings to the job, one's ability to learn and one's motivation to share information and knowledge [11]. Other dimensions of human capital in relation to organizational performance are training and competences, expertise and experience, creativity and innovation [12].

A study which was conducted by reference [13] at the Jordanian Pharmaceutical Companies recommends that improvements or developments in human capital can increase business levels, expand marketing and increase business strength. Numerous studies also recommend that human capital can improve organizational performance [5], [14]. This paper intends to examine whether or not human capital improvement obtained through training is able to impact business development with the model as shown in Figure 1 below:

\section{Figure 1: Human Capital Improvement For Business Development}

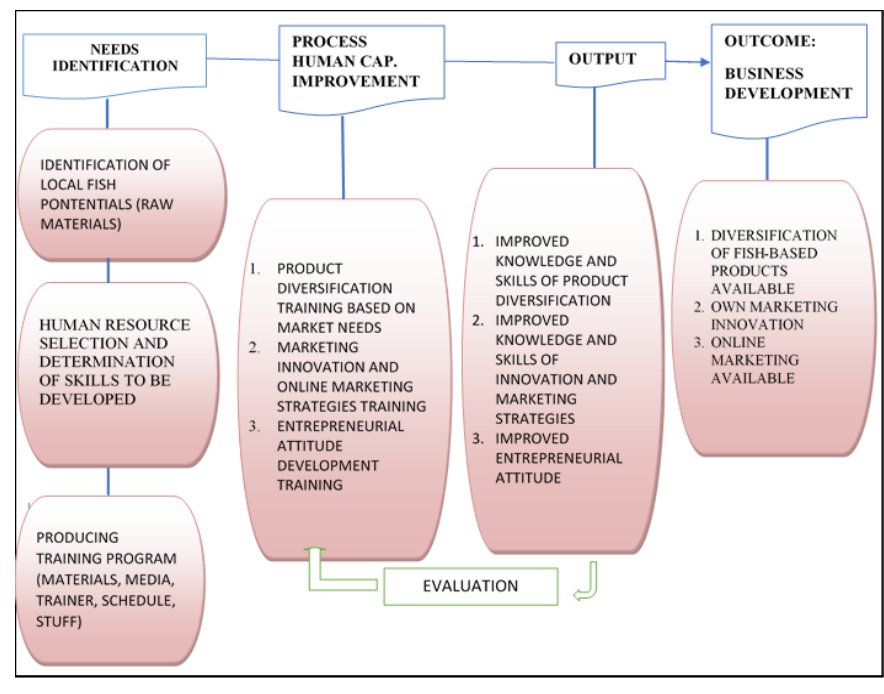

\section{RESEARCH METHODS}

This research utilises experimental method one group pretest-posttest experiment design. Data were collected utilising a questionnaire technique that was selected purposively on 50 "Tibo-tibo" fisherwomen business in North Minahasa Regency who attended the training. There are 2 considerations in determining training participants, who are domiciled in 1 location of 
residence, while other considerations are those who have a commitment to implement business development. Market survey was also held which targets to gain information about fish processing products that have a great opportunity to be developed in line with market needs.

\section{RESULT AND DISCUSSION}

The first step to be conducted to improve human capital through training is to identify the availability of potential local fish that are often sold by women who do Tibo-tibo fish business. The results of the identification and approval of experts that there are 5 types of fish that have the opportunity for product diversification development, namely the Blue Fly fish (Decapterus macarellus) or in the research location known as Malalugis fish, Yellow Tail fish (Caesionidae) which is known by the community as Lolosi fish, Cakalang fish (Katsuwonusus) pelamis) and Tongkol (Euthynnus affinis), and Roa fish (Hemiramphus brasiliensis). Market survey results show that there are several products that have the prospect to be developed in accordance with market demand, such as fish balls, fish nuggets, fish crackers, salted fish and smoked fish. After conducting training related to human capital improvement, then conducting a test whose data is confirmed by $\mathrm{T}$ test in order to discover whether or not there are differences before and after training. The next step is to apply a regression test which is intended to find out the effect of human capital improvement on business development. The test results are as follows:

\section{Difference test of two averages}

Table 1: Human Capital Average Test (HC)

\begin{tabular}{|c|c|c|c|c|c|}
\hline \multicolumn{5}{|c|}{ Group Statistics } \\
\hline & CODE & $\mathrm{N}$ & Mean & $\begin{array}{c}\text { Std. } \\
\text { Deviation }\end{array}$ & $\begin{array}{c}\text { Std. Error } \\
\text { Mean }\end{array}$ \\
\hline \multirow{4}{*}{$\mathrm{HC}$} & Pre & 55 & 41.65 & 4.448 & .600 \\
\cline { 2 - 6 } & & & & & \\
& Post & 55 & 72.78 & 3.994 & .539 \\
& & & & & \\
\hline
\end{tabular}

Table 2: Difference Test Before and After Training

\begin{tabular}{|c|c|c|c|c|c|c|c|c|c|c|}
\hline & & \multicolumn{2}{|c|}{$\begin{array}{l}\text { Levene's Test } \\
\text { for Equality } \\
\text { of Variances }\end{array}$} & \multicolumn{7}{|c|}{ t-test for Equality of Means } \\
\hline & & & & & & & & & \multicolumn{2}{|c|}{$\begin{array}{l}95 \% \text { Confidence } \\
\text { Interval of the } \\
\text { Difference }\end{array}$} \\
\hline & & $\mathrm{F}$ & Sig. & $\mathrm{t}$ & df & $\begin{array}{l}\text { Sig. (2- } \\
\text { tailed) }\end{array}$ & $\begin{array}{c}\text { Mean } \\
\text { Difference }\end{array}$ & $\begin{array}{l}\text { Std. Error } \\
\text { Difference }\end{array}$ & Lower & Upper \\
\hline \multirow[t]{2}{*}{$\mathrm{HC}$} & $\begin{array}{l}\text { Equal variances } \\
\text { assumed }\end{array}$ & 1.387 & .242 & \begin{tabular}{|l|}
-38.615 \\
\end{tabular} & 108 & .000 & -31.127 & .806 & \begin{tabular}{|l|l|}
62.725 \\
\end{tabular} & -29.529 \\
\hline & $\begin{array}{l}\text { Equal variances } \\
\text { not assumed }\end{array}$ & & & -38.615 & 106.771 & .000 & -31.127 & .806 & $6-32.725$ & -29.529 \\
\hline
\end{tabular}

Different test results obtained $t$ Value Equal Variance of $-38,615$ with Sig. (2-tailed) is 0,000 or less than 0.05 , thus it can be stated that there are differences for those who have attended the training and those who have not attended the training yet. This exhibits that Tibo-tibo fisherwomen's knowledge and skills about product diversification, marketing innovation and online marketing strategies as well as entrepreneurial attitudes are improved by attending the training.

\section{Regression Analysis}

At this stage a Bivariate Test $(\mathrm{Y}=\mathrm{a}+\mathrm{bX})$ results are shown as follows:

Table 3: Model Summary

\begin{tabular}{|c|c|r|r|c|}
\hline \multicolumn{5}{|c|}{ Model Summary } \\
\hline Model & $\mathrm{R}$ & R Square & $\begin{array}{c}\text { Adjusted } \\
\text { R Square }\end{array}$ & $\begin{array}{c}\text { Std. Error of the } \\
\text { Estimate }\end{array}$ \\
\hline 1 & $.948^{\mathrm{a}}$ & .898 & .896 & .742 \\
\hline \multicolumn{5}{|c|}{ a. Predictors: (Constant), Human Capital } \\
\hline
\end{tabular}

Table 4 : Coefficients ${ }^{\mathrm{a}}$

\begin{tabular}{|c|c|c|c|c|c|c|}
\hline \multicolumn{7}{|c|}{ Coefficients $^{\mathrm{a}}$} \\
\hline \multirow{2}{*}{\multicolumn{2}{|c|}{ Model }} & \multicolumn{2}{|c|}{$\begin{array}{l}\text { Unstandardized } \\
\text { Coefficients }\end{array}$} & \multirow{2}{*}{\begin{tabular}{|c|}
$\begin{array}{c}\text { Standardize } \\
\mathrm{d} \\
\text { Coefficients }\end{array}$ \\
Beta \\
\end{tabular}} & \multirow[b]{2}{*}{$\mathrm{t}$} & \multirow[b]{2}{*}{ Sig. } \\
\hline & & B & $\begin{array}{l}\text { Std. } \\
\text { Error }\end{array}$ & & & \\
\hline \multirow[t]{2}{*}{1} & (Constant) & 6.120 & 1.842 & & 3.323 & .002 \\
\hline & $\begin{array}{l}\text { Human } \\
\text { Capital }\end{array}$ & .546 & .025 & .948 & 21.617 & .000 \\
\hline \multicolumn{7}{|c|}{ a. Dependent Variable: Bus. Development } \\
\hline
\end{tabular}

The results of the analysis of human capital's influence on business development is significant in which Human Capital variable is $0,000<0.05$, hence it can be concluded that there is a direct significant effect between human capital and business development. The results exhibited that the amount of the contribution of human capital to business development was 0.898 meaning that the improvement in human capital influenced significantly the development of informal businesses held by Tibo-tibo fisherwomen.

\section{CONCLUSION}

The findings of this study conclude that there are differences in the ability of human capital before attending training and after attending training. These results indicate that there was an increase in human capital for respondents who have attended training in the form of improved knowledge and product diversification 
skills, improved marketing innovation and online marketing strategies and changes in entrepreneurial attitudes. The results of subsequent studies stated that human capital improvement will affect the development of business applied by Tibo-tibo fisherwomen in North Minahasa Regency. The model of human capital improvement has changed the business behaviour of traditional business behaviour which is previously only selling fresh fish in the market and or going around with baskets to the villages, to a new business behaviour as indicated by the availability of diversified quality local fish-based processed products, sizes and prices are various and online based marketing is implemented. The human capital improvement model does not ignore the main activity of Tibo-tibo which only sells fresh fish but develops or expands the activities into more innovative business models.

\section{ACKNOWLEDGMENT}

The author would like to acknowledge the Rector of Manado State University in supporting the publication of this article.

\section{REFERENCES}

[1] C. S. Marques, G. Santos, V. Marques, and A. Lama, 'The Role of Informal MicroEntrepreneurs in the Development of a Rural Border Region', in International Conference on Innovation and Entrepreneurship, 2018, pp. 450XVI.

[2] S. Marjit and B. Mandal, 'International Trade, Migration and Unemployment-The Role of Informal Sector', Econ. Polit., vol. 28, no. 1, pp. 8-22, 2016.

[3] A. F. Safaria, D. Suhanda, and S. Riawanti, Hubungan perburuhan di sektor informal: permasalahan dan prospek. Akatiga, 2003.

[4] P. E. Bangasser, The ILO and the informal sector: an institutional history. ILO Geneva, 2000.

[5] R. Hejazi, M. Ghanbari, and M. Alipour, 'Intellectual, human and structural capital effects on firm performance as measured by Tobin's Q', Knowl. Process Manag., vol. 23, no. 4, pp. 259-
273, 2016.

[6] M. J. Hashim, I. Osman, and S. M. Alhabshi, 'Effect of intellectual capital on organizational performance', Procedia-Social Behav. Sci., vol. 211, pp. 207-214, 2015.

[7] T. Kim, W. G. Kim, S. S. Park, G. Lee, and B. Jee, 'Intellectual Capital and Business Performance: What Structural Relationships Do They Have in Upper-Upscale Hotels?', Int. J. Tour. Res., vol. 14, no. 4, pp. 391-408, 2012.

[8] N. Bontis, 'Intellectual capital: an exploratory study that develops measures and models', Manag. Decis., 1998.

[9] A. Baron and M. Armstrong, Human capital management: achieving added value through people. Kogan Page Publishers, 2007.

[10] N. Bosma, M. Van Praag, R. Thurik, and G. De Wit, 'The value of human and social capital investments for the business performance of startups', Small Bus. Econ., vol. 23, no. 3, pp. 227-236, 2004.

[11] J. Fitz-Enz, The ROI of human capital: Measuring the economic value of employee performance. AMACOM Div American Mgmt Assn, 2000.

[12] Ş. Zlate and C. Enache, 'The interdependence between human capital and organizational performance in higher education', Procediasocial Behav. Sci., vol. 180, pp. 136-143, 2015.

[13] M. S. Y. ALmasarweh, 'The impact of human capital on competitive performance: an empirical study on Jordanian pharmaceutical companies', Eur. Sci. J., vol. 12, no. 4, 2016.

[14] M. J. Hashim, I. Osman, and S. M. Alhabshi, 'Effect of Intellectual Capital on Organizational Performance', Procedia - Soc. Behav. Sci., vol. 211, no. September, pp. 207-214, 2015. 